\title{
Preliminary study on diversity of intertidal gastropods in Barangay Day-asan, Surigao City, Philippines
}

\author{
Vince R. Abarquez*, Noe P. Mendez and Gloria L. Galan \\ Department of Biology, College of Arts and Sciences, Central Mindanao University, University \\ Town, Musuan 8710 Bukidnon, Philippines \\ *Correspondence: vinceromanoabarquez@gmail.com; iD https://orcid.org/0000-0002-2814-0780
}

Received: $2^{\text {nd }}$ August 2018, Revised: $11^{\text {th }}$ January 2019, Accepted: $12^{\text {th }}$ March 2019

\begin{abstract}
Unregulated harvesting and habitat degradation of marine gastropods are major anthropogenic activities done by the local people in Barangay Day-asan, Surigao City, Philippines. This study was undertaken to determine the diversity of marine gastropods found in the intertidal of Dapya Island. Collection of specimens was done through hand picking and beachcombing methods in the three established study stations. Data revealed a total of 184 individuals belonging to 37 species in 5 orders, 15 families and 25 genera. The order Neogastropoda obtained the highest number of species with 15 species, followed by order Mesogastropoda with 10 species, order Archaeogastropoda with 7 species, order Neritopsina with 4 species and order Caenogastropoda with one species. Among the 37 species, Nerita undata was the most abundant. Shannon-Weiner diversity index revealed that station $2(\mathrm{H}=1.193)$ obtained the highest species diversity, followed by station $3(\mathrm{H}=1.103)$ and station $1(\mathrm{H}=1.063)$. The Bray-Curtis analysis of species composition showed two different clusters of habitat. Cluster 1 is composed of two related habitats joined by Stations 1 and 2 with $S_{i}=54.26 \%$ and cluster 2 composed of Stations 3 and 1 with $S_{i}=40.65 \%$. Furthermore, among the 37 species, six of which were concordant in all study stations viz., Angaria delphinus, Astralium calcar, Conus miles, Lambis lambis, Euprotomus bulla and Canarium labiatum. The results of the study showed a low diversity of intertidal gastropods in Barangay Day-asan. The area is known to be the most gleaned by locals and it is been already disturbed due to over-harvesting of gastropod species.
\end{abstract}

Keywords: Angaria delphinus, Conus miles, Dapya Island, Nerita undata, Surigao del Norte.

\section{Introduction}

Gastropoda is the largest molluscan class, containing more than half of all living mollusc species. Gastropods, commonly known as snails and slugs, are distributed among marine, freshwater and terrestrial environments, and occupy diverse habitats, including rivers, trees, deserts, marine intertidal zone 
and the deep sea (Pechenik 2011). Gastropods are an important source of food in the Filipino diet for its delectable taste. Gastropod shells are widely collected, traded, bought and sold because of the beauty and attractiveness of each variety. They are also used for the preparation as decorative and household items which find their way to both local and foreign markets (PCAARRD 1988). On the other hand, some species of gastropods act as intermediate host for some medically important trematode parasites of human (Miller and Harley 2002).

One of the major places where people harvest gastropods in the Philippines is the Dapya Island. This island is located in Surigao City, the gateway to Mindanao and is one of the many cities endowed with extraordinary gifts. According to barrio folks, during older days, various untamed fishes appeared and came along the sea water because of the presence of mangrove trees which grow in swampy places that surrounds Barangay Day-asan. Dapya Island has a large tidal flat and it is abundant with marine life including gastropods. Since these gastropods are harvested not only for food but also sold for livelihood, there might be possible danger of losing some gastropod species through this action. Furthermore, these gastropods have also not been documented and listed, and there is no regulated policy in the area which will limit the people from over-gleaning the gastropod species. Although the Philippines is considered as a mega-diverse country in terms of molluscs, studies on mollusc diversity in Mindanao is considerably scarce (Jumawan et al. 2015). Additionally, molluscs had the highest number of documented extinctions among the major taxonomic groups in the world (Lydeard et al. 2004). Thus, this study was undertaken to determine the diversity of intertidal gastropods in Barangay Day-asan, Surigao City. Similarity indices and physico-chemical parameters were also tested in the study sites.

\section{Material and Methods}

\subsection{Study site}

The study was conducted in Dapya Island, Brgy. Day-asan, Surigao City, Philippines (Figure 1). Day-asan is just $15 \mathrm{~km}$ away from the Surigao City Hall and can be accessed either by motorboat ride or land vehicle. According to Edera (2010), Day-asan is located at Arellano District with a total land area of 3,040.447 ha, of which 554 ha are mangrove forests. There are 1,572 inhabitants and a total of 341 households. 


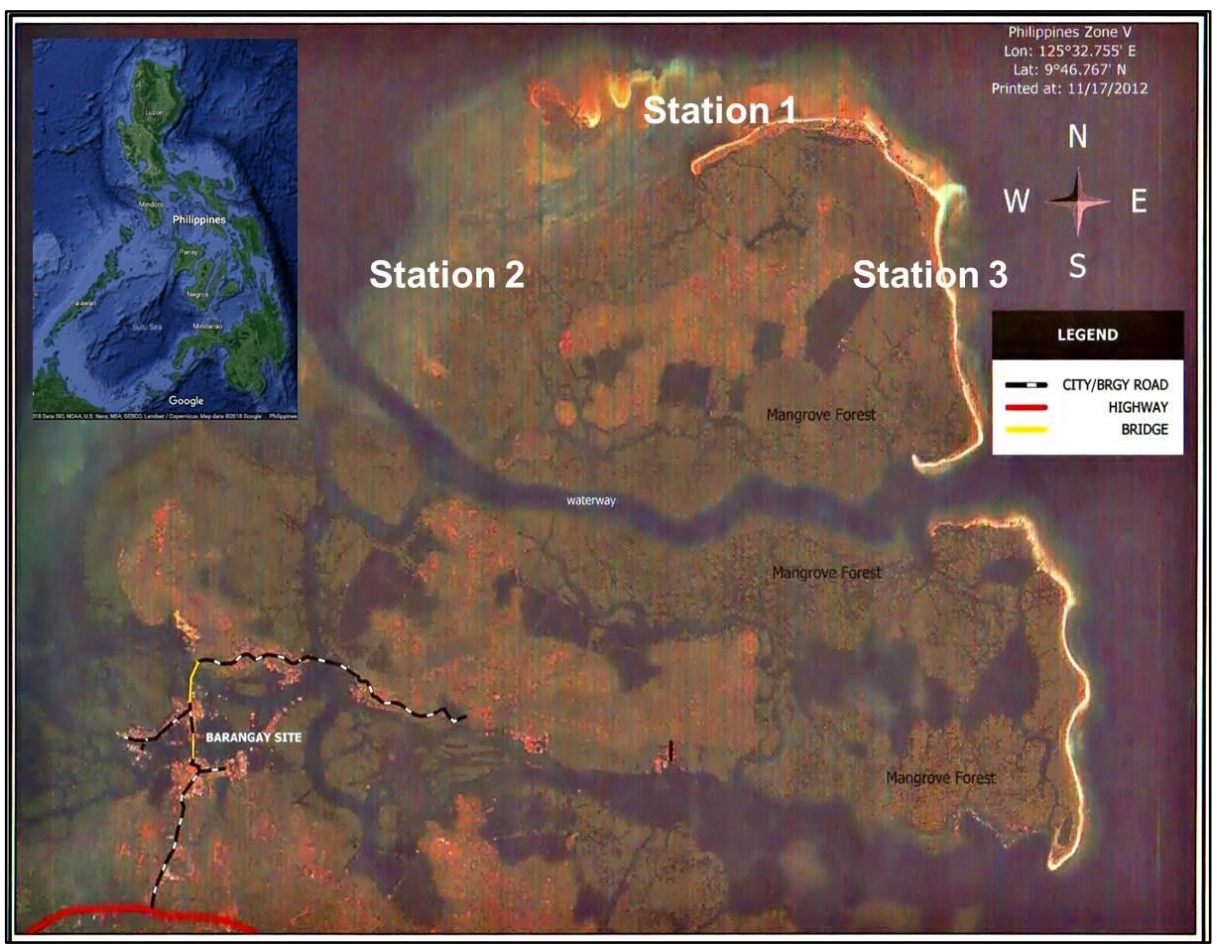

Fig 1. Map of Dapya Island showing the three study stations (inset: Philippine map).

Three study stations were selected in the study site, and the exact position and elevation of the three study stations designated as Study Station 1, Station 2 and Station 3 were recorded using the Global Positioning System (GPS) apparatus. A $50 \mathrm{~m}$ belt transect line was laid in each station from landward to seaward with the width of $1 \mathrm{~m}$ (total area of $50 \times 1 \mathrm{~m}^{2}$ ). A total of 50 quadrats were established per station with an area of $1 \mathrm{~m}^{2}$, and were numbered from 1 to 50 (Q1-Q50). Three established station plots had a distance of approximately $100 \mathrm{~m}$ apart from each other. This method followed that of Henderson (2003), which stated that the sampling can be based on the number of quadrates in order to come up with the requirements for determining the species diversity.

Station 1 faces the open water of Surigao with a rocky shoreline (big boulders of rocks), mixed sandy and coralline with some rocks in the substratum. It was abundant in seaweeds and sea grasses, and in marine fauna including gastropods. Station 2 was $100 \mathrm{~m}$ away from station 1 with almost the same habitat type but closer to the mangrove area. The fauna associates in Station 2 like the sea stars were lower compared to station 1 . Station 3 was established near a mangrove ecosystem which has a rocky shoreline (big 
boulders of rocks). The substratum is mixed rocky and coralline, seaweeds and sea grasses were also abundant but fauna associates were lower compared to the other stations.

\subsection{Collection of specimens}

Collection of gastropods was done within the established quadrats through hand picking and beach combing from November 2012 - January 2013. The gastropod species were hand-picked or removed using sharp objects like a knife. Stone and debris were removed and a hand shovel was used to dig out substrate cover and transferred to a sieve to extract smaller gastropods. The specimens were properly placed in labeled cellophane bags for identification. Representative specimens were brought to the Biology laboratory room of the College of Arts and Sciences, Central Mindanao University, Musuan, Bukidnon for further processing.

\subsection{Classification and identification of specimens}

The specimens were classified and identified using standard taxonomic keys and books of Garcia (1986) and Laureta (2008) and literature (e.g., Tabugo et al. 2013; Sosa et al. 2014; Dolorosa, Dangan-Galon 2014; Cuadrado 2015; Jumawan et al. 2015; Ramos et al. 2018). Identification was made as far as possible to Order, Family, Genus and Species.

\subsection{Diversity indices}

The following biodiversity indices were determined using BioPro Software version 2.0 of McAleece (2001). The raw data from the line transect were entered into a spread sheet application such as Microsoft excel and open orgcalculation. The spread sheet file was loaded to the biodiversity professional application software which processed data and interpreted as plots and tables (Mac Aleece 2001). The diversity indices were obtained using the formulas of Eskandar and Kotonegara (1993) as follows:

Shannon-Weiner index across study stations

$$
\mathrm{H}^{\prime}=\left[\sum\left(\mathrm{p}_{\mathrm{i}} / \ln \mathrm{p}_{\mathrm{i}}\right)\right]
$$

Where: $\mathrm{H}=$ Shannon Index

' $\mathrm{p}_{\mathrm{i}}{ }^{\prime}=$ represents the proportion of total sample belong to each species

'In $\mathrm{p}_{\mathrm{i}}$ ' $=$ represents the natural logarithm 
Similarity indices of species composition using Bray-Curtis across study stations by,

$$
\mathrm{S}_{\mathrm{i}}=\mathrm{C} /(\mathrm{a}+\mathrm{b}+\mathrm{c}) \times 100
$$

Where: $\mathrm{S}_{\mathrm{i}}=$ species composition

$\mathrm{C}=$ total species common to all stations

$\mathrm{a}=$ study station 1

$\mathrm{b}=$ study station 2

$\mathrm{c}=$ study station 3

\subsection{Physico-chemical parameters}

The following environmental conditions were reported following Odum (1971):

a. Temperature: Three reading of the water temperature was taken by submerging the laboratory thermometer in the water surface for five minutes. The average temperature was calculated.

b. Substrate: The substrate of each study station was classified as sandy, rocky, muddy, or coralline. Associated flora and fauna were also noted.

c. Transparency: A secchi disc was submerged in the water until the disc disappeared. Reading was recorded and then lifted slowly until the white disc reappeared for the second reading. The averages of the first and second readings were measured for turbidity. This was done three times and the average was then calculated for each station.

d. $\mathrm{pH}$ : Determination of water $\mathrm{pH}$ was done using $\mathrm{pH}$ paper submerged in the water for three times and referred to a standard color chart and calculated.

e. Tidal level: Tidal determination was based on the tidal calendar record.

\subsection{Preservation of specimens}

Specimens were secured in the labelled cellophane bags and the foot and visceral mass were carefully extracted from the shell. The shells were then cleaned using soap and detergent and carefully brushed to remove any debris. They were cleaned further using a $10 \%$ Gleam muriatic acid. After which, the shells were air-dried, packed and labelled for identification. Voucher specimens were deposited at the Zoology section of Central Mindanao University Museum, Musuan, Bukidnon, Philippines. 


\section{Results and Discussion}

\subsection{Species composition}

A total of 184 individuals belonging to 37 species were found in the area. These belong to five orders, 15 families and 25 genera (Fig. 2).

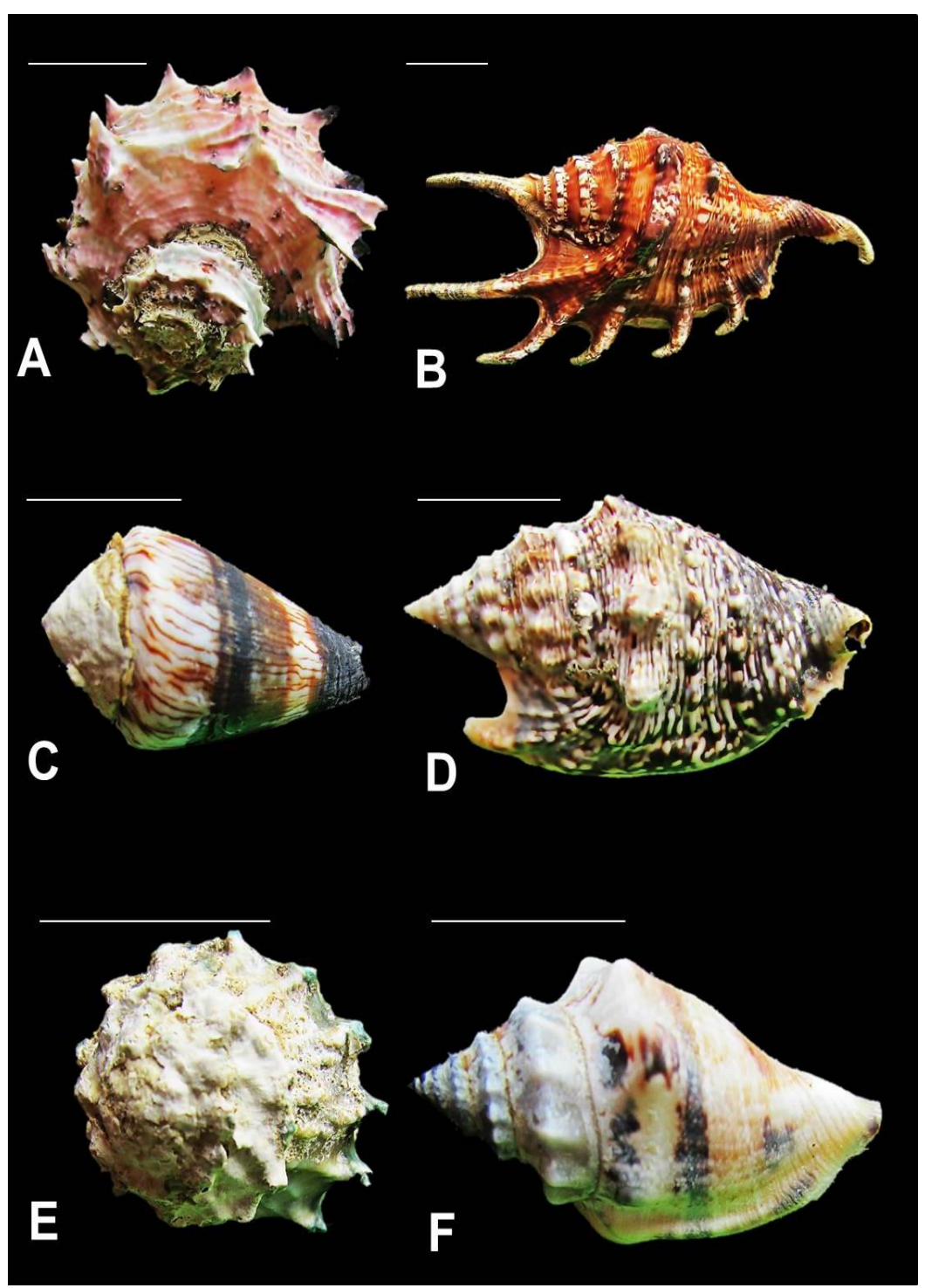

Fig 2. Representative species collected in the study sites. A) Angaria delphinus, B) Lambis lambis, C) Conus miles, D) Euprotomus bulla, E) Astralium calcar, F) Canarium labiatum. Scale bars $=2 \mathrm{~cm}$. 
The order Neogastropoda had the highest number of families with six families, followed by orders Mesogastropoda and Archaeogastropoda with four families each and orders Neritopsina and Caenogastropoda with one family each. Family Cypraeidae had the highest number of species recorded with six species and lowest in numbers were the families Chilontidae, Trochidae, Potamidae, Angariidae, Buccinidae, Turbenillidae and Volutidae represented with only one species (Table 1).

Table 1. Species composition of intertidal gastropods in the three study stations.

\begin{tabular}{|c|c|c|c|c|}
\hline \multirow[t]{2}{*}{ Family/ Species } & \multicolumn{3}{|c|}{$\begin{array}{c}\text { Number of } \\
\text { individuals per } \\
\text { station }\end{array}$} & \multirow[t]{2}{*}{$\begin{array}{l}\text { Total number o } \\
\text { individuals } \\
\text { per species }\end{array}$} \\
\hline & S1 & S2 & S3 & \\
\hline \multicolumn{5}{|l|}{ I. Order Archeogastropoda } \\
\hline \multicolumn{5}{|l|}{ Family Chilontidae } \\
\hline Euchelus atratus (Gmelin, 1791) & 3 & 0 & 0 & 3 \\
\hline \multicolumn{5}{|l|}{ Family Tegulidae } \\
\hline Tectus pyramis (Born, 1778) & 2 & 0 & 2 & 4 \\
\hline Tectus fenestratus (Gmelin, 1791) & 7 & 0 & 6 & 13 \\
\hline \multicolumn{5}{|l|}{ Family Trochidae } \\
\hline Trochus masculatus & 0 & 1 & 0 & 1 \\
\hline \multicolumn{5}{|l|}{ Family Turbinidae } \\
\hline Astralium calcar (Linnaeus, 1758) & 2 & 2 & 6 & 10 \\
\hline Turbo bruneus (Roding, 1798) & 2 & 0 & 3 & 5 \\
\hline Lunella cinerea (Born, 1778) & 0 & 1 & 0 & 1 \\
\hline \multicolumn{5}{|l|}{ II. Order Caenogastropoda } \\
\hline \multicolumn{5}{|l|}{ Family Potamididae } \\
\hline Terebralia palustris (Linnaeus, 1767) & 0 & 0 & 11 & 11 \\
\hline \multicolumn{5}{|l|}{ III. Order Mesogastropoda } \\
\hline \multicolumn{5}{|l|}{ Family Angariidae } \\
\hline Angaria delphinus (Linnaeus, 1758) & 10 & 4 & 6 & 20 \\
\hline \multicolumn{5}{|l|}{ Family Cerithidae } \\
\hline Cerethium nodulosum (Bruguiere, 1792) & 0 & 0 & 1 & 1 \\
\hline \multicolumn{5}{|l|}{ Family Cyperaeidae } \\
\hline Cypraea sp. 1 & 0 & 3 & 1 & 4 \\
\hline Cypraea sp. 2 & 0 & 1 & 0 & 1 \\
\hline Cypraea sp. 3 & 0 & 1 & 0 & 1 \\
\hline Erosaria errones (Linnaeus, 1758) & 0 & 1 & 0 & 1 \\
\hline Erronea erosa (Linnaeus, 1758) & 0 & 1 & 0 & 1 \\
\hline Mauritia eglantina (Duclos, 1833) & 0 & 0 & 2 & 2 \\
\hline \multicolumn{5}{|l|}{ Family Naticidae } \\
\hline Natica fasciata (Roding, 1798) & 0 & 1 & 0 & 1 \\
\hline Polinices lacteus (Guilding, 1834) & 0 & 1 & 0 & 1 \\
\hline \multicolumn{5}{|l|}{$\begin{array}{l}\text { IV. Order Neogastropoda } \\
\text { Family Buccinidae }\end{array}$} \\
\hline Cantharus sp. & 3 & 0 & 0 & 3 \\
\hline
\end{tabular}


Table 1 Continued

\begin{tabular}{|c|c|c|c|c|}
\hline \multirow[t]{2}{*}{ Family/ Species } & \multicolumn{3}{|c|}{$\begin{array}{c}\text { Number of } \\
\text { individuals per } \\
\text { station }\end{array}$} & \multirow[t]{2}{*}{$\begin{array}{l}\text { Total number of } \\
\text { individuals } \\
\text { per species }\end{array}$} \\
\hline & S1 & S2 & S3 & \\
\hline \multicolumn{5}{|l|}{ Family Conidae } \\
\hline Conus capitaneus (Linnaeus, 1758) & 0 & 1 & 3 & 4 \\
\hline Conus marmoreus (Linnaeus, 1758) & 1 & 0 & 0 & 1 \\
\hline Conus miles (Linnaeus, 1758) & 3 & 7 & 5 & 15 \\
\hline Conus sp. 1 & 0 & 1 & 0 & 1 \\
\hline Conus sp. 2 & 0 & 1 & 0 & 1 \\
\hline \multicolumn{5}{|l|}{ Family Muricidae } \\
\hline Chicoreus torrefactus (Sowerby, 1841) & 0 & 0 & 1 & 1 \\
\hline Chicoreus brunneus (Link, 1807) & 0 & 0 & 1 & 1 \\
\hline \multicolumn{5}{|l|}{ Family Strombidae } \\
\hline Canarium maculatum (Sowerby, 1842) & 0 & 2 & 0 & 2 \\
\hline Canarium labiatum (Röding, 1798) & 3 & 1 & 1 & 5 \\
\hline Euprotomusbulla (Roding, 1798) & 2 & 2 & 1 & 5 \\
\hline Gibberulus gibberulus (Linnaeus, 1758) & 0 & 2 & 0 & 2 \\
\hline Lambis lambis (Linnaeus, 1758) & 2 & 3 & 3 & 8 \\
\hline \multicolumn{5}{|l|}{ Family Turbinellidae } \\
\hline Vasum turbinellus (Linnaeus, 1758) & 0 & 0 & 2 & 2 \\
\hline \multicolumn{5}{|l|}{ Family Volutidae } \\
\hline Cymbiola vespertilio (Linnaeus, 1758) & 2 & 1 & 0 & 3 \\
\hline \multicolumn{5}{|l|}{ V. Order Neritopsina } \\
\hline Nerita undata (Linnaeus, 1758) & 16 & 15 & 0 & 31 \\
\hline Nerita polita (Linnaeus, 1758) & 8 & 5 & 0 & 13 \\
\hline Nerita plicata (Linnaeus, 1758) & 2 & 0 & 0 & 2 \\
\hline Nerita albicilla (Linnaeus, 1758) & 0 & 3 & 0 & 3 \\
\hline Total number of individuals & 16 & 24 & 17 & 184 \\
\hline
\end{tabular}

The time span of the collection of Berdach (1981) was 37 years ago. It could be attributed to many environmental changes like habitat degradation due to anthropogenic activities like the establishing of fish pens, over gleaning and overharvesting, gathering of mangrove trees for firewood and for recreational activities. Most of the marine gastropods are economically important. They are harvested by the town folks as food, sold in markets for livelihood and collected for shell ornaments. This probably results in low number of species found in the area. The major species harvested in the area were from the genus Lambis (pers. comm.). As observed, this species was few in number compared to other species collected.

Habitat degradation, unregulated harvesting, cutting of mangrove forest and improper waste disposal in the study sites are possible threats that cause gastropod depletion in the area similar to the report of Dolorosa and Dangan- 
Galon (2014) in Iwahig River-Estuary of Palawan. As reported by earlier studies, gleaning or collection of edible molluscs is a common practice in the Philippines since these organisms are used either for personal consumption or as additional earnings (Nieves et al. 2010, Napata and Andalecio 2011, Masangcay and Lacuna 2017). It is also important to conserve the gastropod species in the area since some species of Family Strombidae are the usual species collected by the local people.

\subsection{Species diversity}

\section{Shannon-Weiner diversity index}

The diversity of gastropod species was highest in Station $2\left(\mathrm{H}^{\prime}=1.193\right)$, followed by Station $3\left(\mathrm{H}^{\prime}=1.103\right)$ and lowest in Station $1\left(\mathrm{H}^{\prime}=1.063\right)$ (Table 2).

Table 2. Results of Shannon-Weiner diversity index.

\begin{tabular}{llll}
\multicolumn{1}{c}{ Index } & \multicolumn{1}{c}{ S1 } & \multicolumn{1}{c}{ S2 } & \multicolumn{1}{c}{ S3 } \\
\hline Shannon H' Log Base 10. & 1.063 & 1.193 & 1.103 \\
Shannon Hmax Log Base 10. & 1.204 & 1.38 & 1.23 \\
Shannon J' & 0.883 & 0.864 & 0.896
\end{tabular}

Legend: S1 = Station 1; S = Station 2; S3 = Station 3

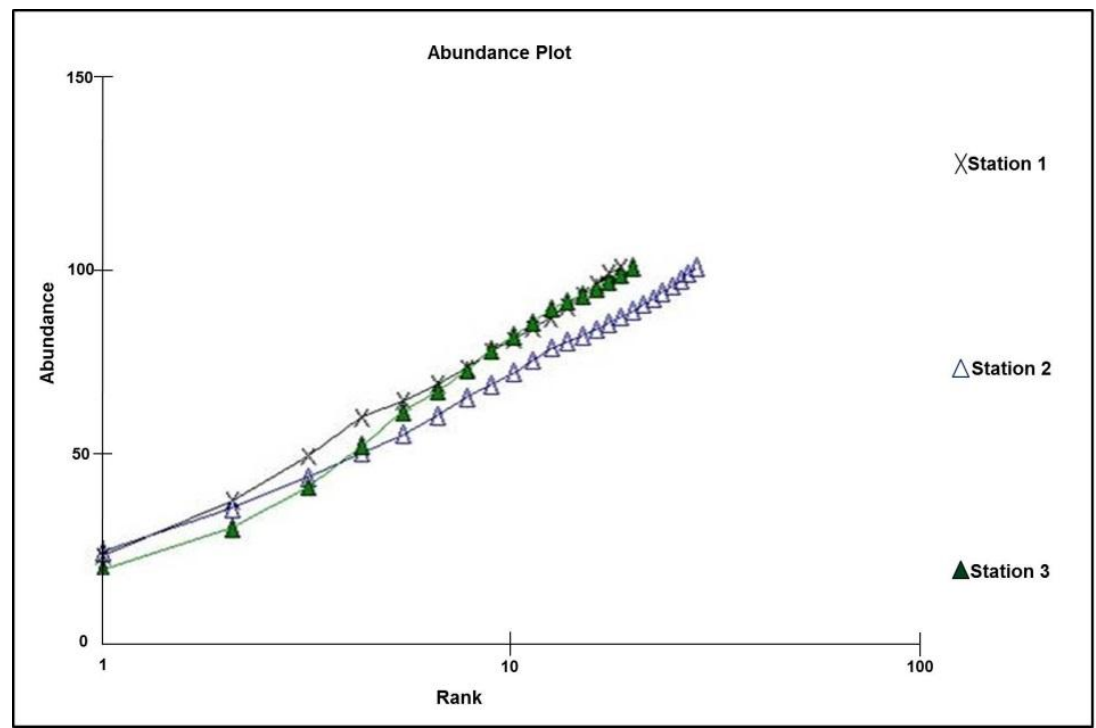

Fig 3. K-plot of species abundance of marine gastropods in Barangay Day-asan, Surigao City. 
The diversity of gastropods in Barangay Day-asan is low which also support the Philippine studies on gastropods by Berdach (1981) in Puerto Galera, and Flores and Zafaralla (2012) in Mananga River in Cebu. Since the values obtained for Shannon-Weiner diversity index are less than 2.5, this study implies that the three sites have low diversity index as none of them obtained a value higher than 2.5 (Flores and Zafaralla 2012).

In the species accumulation curve, the study shows that the data is sufficient for the diversity index analysis (Figure 3). However, as mentioned by Cuadrado (2015), this low diversity index value of the three sites would make sense if the sampling was done in a longer period of time.

\section{Similarity Index}

The results showed clustering of marine gastropod species in stations 1 and 2 maybe because these two stations were on the same side of the island. Species in station 3 in the dendrogram (Figure 4) appeared as a different cluster and branched to other stations because this station was established in other side of the island specifically nearer to the mangrove area. The species in station 3 were seemed to be unique, which supported by the dendrogram.

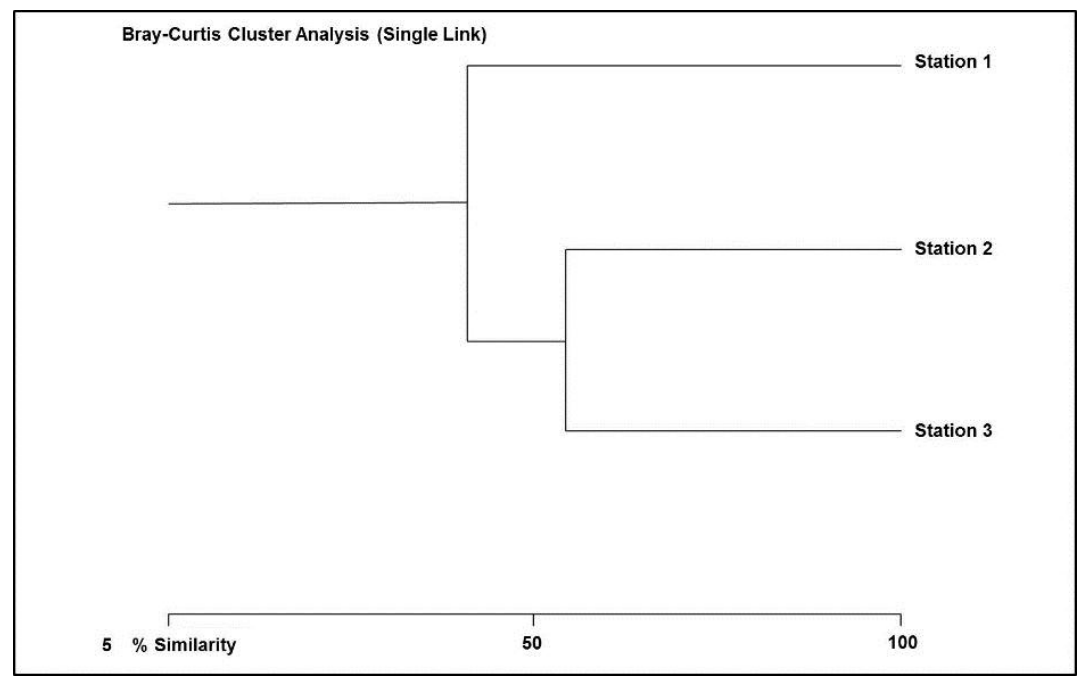

Fig 4. Dendrogram of similarity species composition of marine gastropods in Barangay Day-asan, Surigao City.

\subsection{Species distribution}

Among the species collected, four species were observed only in station 1 . These species were Nerita plicata, Euchelus atratus, Conus marmoreus and 
Cantharus sp. Eleven species were found only in station 2 viz., Nerita albicilla, Lunella cinerea, Trochus masculatus, Conus sp. 1, Conus sp. 2, Cypraea sp. 2, Cypraea sp. 3, Cypraea errones, Cypraea errosa, Natica fasciata and Polinices lacteus and six species were only found in station 3 viz., Terebralia sp., Vasum turbinellus, Chicoreus torrefactus, Chicoreus brunneus, Cypraea eglantina and Cerithium nodulosum. Species found in stations 1 and 2 had similarity in the species composition, while the species in station 3 differed from the other stations.

There were six species which had the widest range of distribution concordant in all study stations viz., Angaria delphinus, Astralium calcar, Conus miles, Lambis lambis, Euprotomus bulla and Canarium labiatum. The diversity of marine gastropods in Barangay Day-asan showed similarity with two clusters in the dendrogram. Cluster 1 showed the two closely related habitats namely: station 1 and station 2 with $S_{i}=54.26 \%$ of species composition, while cluster 2 consists of stations 1 and 3 with $S_{i}=40.65 \%$.

The most abundant species in station 1 was $N$. undata. Nerites prefer brackish water systems and supported the recorded water $\mathrm{pH}$ which was 9 . Moreover, they were found on rocky substrates where seaweed was abundant. The tide is an important environmental factor influencing the mobility of the organisms and their exposure to air and water. The tidal levels also affect the species distribution. Also, station 1 favored the presence of many sea stars of which gastropods are one of its preys. For the distribution of $N$. undata, since it is attached in rocks on the shoreline, it is not been preyed by the sea stars which also reflects to the abundance of the species in the station.

For the species frequency, $N$. undata was only seen in 1 out of 50 quadrates, since they were distributed and can be seen in clumps or living together because they are said to be gregarious animals (Tan and Clements 2008). Angaria delphinus on the other hand is the frequently seen species since it was found in 7 out of 50 quadrats found scattered along the study station areas.

In station 2, still $N$. undata was the most abundant species. Same observation was done with study station 1 which was established on the same part of the Island. The presence of fauna associates like sea stars was lesser than compared to station 1 . This reflects to number of species found, of which this station is diverse in gastropods. Same environmental factors affected the species in station 1 . For its distribution, they were also seen in 1 quadrate only since they were in clumped distribution. Conus miles was the most frequently seen species in station 2 which was recorded from 7 out of 50 quadrates.

In study station 3, Terebralia sp. was the most abundant species, since this station was established in the other side of the Island, near to a mangrove and exposed to different kinds of environmental factors. This species was present in mangrove area, and since they are mobile, they can be found on the shores of station 3. Furthermore, this species is not consumed by local people and hence it is the least disturbed among the species in station 3. Still, A. delphinus was the most frequently seen species, widely distributed in the 
station which was found in 6 out of 50 quadrates. Flora and fauna associates in the station were less which reflected the disturbance in the area.

\subsection{Physico-chemical parameters}

The mean water temperature in the three stations during the study was $27^{\circ} \mathrm{C}$. The mean water $\mathrm{pH}$ was 9 in the three stations, mean of water salinity was 34 ppt and substrate cover were all mixed with sandy, coralline, rocky and some with boulders of rocks. Flora associates were mainly sea grasses and seaweeds, while the fauna associates were sea stars, sea urchins, sea anemone, hermit crabs and Synapta sp. Sampling in all study stations was done during low tide (Table 3).

Table 3. Summary of physico-chemical parameters in the three study stations.

\begin{tabular}{llll}
\hline Parameters & S1 & S2 & S3 \\
\hline Temperature & $26^{\circ} \mathrm{C}$ & $28^{\circ} \mathrm{C}$ & $27^{\circ} \mathrm{C}$ \\
$\begin{array}{l}\text { Substrate cover } \\
\text { (nature of substrate) }\end{array}$ & $\begin{array}{l}\text { mixed sandy } \\
\text { and rocky }\end{array}$ & $\begin{array}{l}\text { mixed sandy } \\
\text { and rocky }\end{array}$ & $\begin{array}{l}\text { rocky (small to } \\
\text { moderate) substrate } \\
\text { with less sandy } \\
\text { substrate }\end{array}$ \\
& & & Clear \\
Transparency & Clear & Clear & 34 \\
Salinity & 33 & 34 & 9 \\
pH & 8 & 9 & Low tide \\
Tidal measurement & Low tide & Low tide &
\end{tabular}

Strzelec and Krolczyk (2004) stated that many gastropod species are tolerant to most physico-chemical parameters and their occurrence is affected by the quality of bottom sediments and abundance of vegetation. In this study, the physico-chemical factors in the three sites are closely the same. The substrate cover at stations 1 and 2 were similar with mixed sandy and rocky areas. These types of substrate possibly support many gastropods and hence the higher abundance at these two stations. In contrast, gastropods that thrive on rocky substrata prefer station 3, which mainly consists of rocky (small to moderate) substrate. Moreover, the water salinity and $\mathrm{pH}$ in station 3 may be influenced by the mangrove environment.

The physico-chemical parameters like the water temperature, water $\mathrm{pH}$, water salinity and water substratum in the study stations did not very much. Thus, these parameters may fall within the favorable environmental conditions suitable for the growth of gastropods. 


\section{Conclusions and recommendations}

This study revealed that among the 37 species, Nerita undata was the most abundant with a total of 31 individuals. Shannon-Weiner index revealed that station $2(\mathrm{H}=1.193)$ obtained the highest species diversity, followed by station $3(\mathrm{H}=1.103)$ and station $1(\mathrm{H}=1.063)$. The Bray-Curtis analysis of species composition showed two different clusters of habitat. Cluster 1 is composed of two related habitats joined by Stations 1 and 2 with $S_{i}=54.26 \%$ and cluster 2 composed of stations 3 and 1 with $S_{\mathrm{i}}=40.65 \%$. Furthermore, among the 37 species, six were concordant in all study stations viz., $A$. delphinus, A. calcar, C. miles, L.lambis, E. bulla and C. labiatum. Among the species, N. plicata, E. atratus, C. marmoreus and Cantharus sp.1 were the unique species in station 1 . Mixtures of sandy and rocky substrata are the preferred areas of gastropods to inhabit. The environment in station 3 was different from the other two stations due to its proximity to the mangrove.

It is recommended that a yearly survey should be done for a more comprehensive record on gastropods present in the area. These data will be useful for conservation and culture of highly economically important species (e.g., some species from family Strombidae).

\section{Acknowledgments}

The authors are grateful to Prof. Marilou M. Ediza and Prof. Victoria T. Quimpang for their suggestions and comments in this paper. Due acknowledgments are given to Marife S. Servasques for helping in identification and processing of specimens; to Mr. and Mrs. Edgardo Abarquez for financially supporting this study; to the anonymous reviewers for their constructive comments on this paper.

\section{References}

Berdach JT. 1981. Inventory of marine gastropods in the Man and the Biosphere (MAB) Reserve area, Puerto Galera, Oriental Mindoro, Philippines. Philipp. J. Biol. 10(1): 95-108.

Cuadrado JT. 2015. Preliminary Assessment of Freshwater Gastropods in the Selected Rivers in Esperanza, Agusan del Sur, Philippines. The Journal of Zoology Studies 2(4): 13-20. ISSN 2348-5914.

Dolorosa RG, Dangan-Galon F. 2014. Species richness of bivalves and gastropods in Iwahig River-Estuary, Palawan, the Philippines. International Journal of Fisheries and Aquatic Studies 2(1): 207-215. ISSN: 2347-5129.

Edera DC. 2010. Barangay Socio-Economic Profile, Surigao City Planning and Development Office.

Eskandar J, Kontonegara R. 1993. Regional study of Diversity: Concepts and Frameworks and Method Proceedings of SEASIAN University Agro ecosystem Network (SUAN and Program on Environment LENV).West Central Pei Shengii and Precy Sigisie Yunnam. University Press.

Flores MJL, Zafaralla MT. 2012. Macroinvertebrates Composition, Diversity and Richness in Relation to the Water Quality Status of Mananga River, Cebu, Philippines. Philippine Science Letters 5(2): 103-113.

Garcia RF, Natividad VS. 1986. Guide to Philippine Flora and Fauna. Vol. VI. Gastropods, Polecypods, Annelids. Natural Resources Management Center, Ministry of Natural 
Resources and University of the Philippines. JMC Press, Inc. Quezon City, Philippines. 356 pp.

Henderson PA. 2003. Practical Methods in Ecology. 1117 pp. Blackwell Publishing. USA.

Hickman JR, Roberts L, Keen S, Larson A, Eisenhour D. 2003. Animal Diversity. 6th Edition. Mc Graw Hill Company. USA. 171-182 pp.

Jumawan JH, Tripoli FFD, Boquia EES, Niez KLM, Veronilla JAH, Dellomes SA, Udtie RM, Seit NK, Hasim NA, Gatinao MJO. 2015. Species diversity and spatial structure of intertidal mollusks in Padada, Davao del Sur, Philippines. AACL Bioflux 8(3): 301-309.

Laureta LV. 2008. Compendium of the Economically Important Seashells in Panay, Philippines. University of the Philippines Press, Quezon City, Philippines.

Lydeard C, Cowie RH, Ponder WF, Bogan AE, Bouchet P, Clark SA, Cummings KS, Frest TJ, Gargominy O, Herbert DG, Hershler R, Perez KE, Roth B, Seddon M, Strong EE, Thompson FG. 2004. The global decline of nonmarine mollusks. BioScience 54(4): 321-330.

Masangcay SIG, Lacuna MLDG. 2017. Molluscan (Gastropoda and Bivalvia) diversity and abundance in rocky intertidal areas of Lugait, Misamis Oriental, Northern Mindanao, Philippines. Journal of Biodiversity and Environmental Sciences 11(3): 169-179. Accessed at: http://www.innspub.net.

Mc Aleece. 1997. Biodiversity Professional version 2.0 devised by PGD Lambshade, GLJ Paterson and D.J Gage. Programme software. Copyright by the Natural History Museum and Scottish Association for marine Saero.

Miller SA, Harley JP. 2002. Zoology. 5th Edition. 170-179 pp. Mc Graw Hill Company. USA.

Napata RP, Andalecio MN. 2011. Exploitation and Management of Brown Mussel. Natural History Museum Journal 6(2): 113-128.

Nieves PM, de Jesus SC, Macale AMB, Pelea JMD. 2010. An assessment of macroinvertebrate gleaning in fisheries on the Albay Side of Lagonoy Gulf. Kuroshio Science 4(1):27-35.

Odum E. 1971. Fundamentals of Ecology. W. B. Saunders Co. London.

Pechenik JA. 2011. Biology of the Invertebrates. 6th Edition. 215-229 pp. Mc Graw Hill Company. USA.

PCAARRD. 1988. Oyster and Mussel Research. Department of Science and Technology. Los Banos, Laguna.

Ramos DAE, Batomalaque GA, Anticamara JA. 2018. Current Status of Philippine Mollusk Museum Collections and Research, and their Implications on Biodiversity Science and Conservation. Philippine Journal of Science 147(1): 123-163. ISSN 0031-7683

Strzelec M, Królczyk A. 2004. Factors Affecting Snail (Gastropoda) Community Structure in the Upper Course of the Warta River (Poland). Biologia, Bratislava 59(2):159-163.

Tabugo SRM, Pattuinan JO, Sespene NJJ, Jamasali AJ. 2013. Some Economically Important Bivalves and Gastropods found in the Island of Hadji Panglima Tahil, in the province of Sulu, Philippines. International Research Journal of Biological Sciences 2(7): 30-36.

Tan SK, Clements R. 2008. Taxonomy and distribution of Neritidae (Mollusca: Gastropoda) in Singapore. Zoological Studies 47: 481-494. 